\title{
Alpha- and beta-adrenergic receptor blockade in the treatment of hypertension
}

\author{
P. A. Majid, M. K. Meeran, M. E. Benaim, ${ }^{1}$ B. Sharma and S. H. Taylor \\ From the Cardiovascular Unit, University Department of Medicine, The General Infirmary, Leeds
}

The effects of single and combined selective blockade of the sympathetic alpha- and beta-receptors were examined in patients with severe hypertension (diastolic pressure $>120 \mathrm{mmHg}$ ) uncomplicated by cardiac or renal failure. Given intravenously to 12 patients the alpha-receptor antagonist phentolamine and the beta-receptor antagonist oxprenolol together produced a reduction in systemic arterial pressure to normal levels and a reduction in left ventricular end-diastolic pressure without change in the cardiac output; these effects were maintained. Separately, neither drug resulted in such a satisfactory circulatory reponse. In 6 patients continued oral treatment for 6 months with progressively increased doses of oxprenolol alone up to $480 \mathrm{mg}$ daily, in divided doses, produced a moderate reduction in blood pressure. The addition of oral phentolamine $20 \mathrm{mg}$ t.d.s. resulted in an immediate reduction of blood pressure to normal levels, both at rest and during walking, without postural or other side effects, and without habituation to treatment over a period of 6 months. Arguments are presented that such treatment may have significant advantages over other current medicinal treatments of severe hypertensive vascular disease.

In uncomplicated essential hypertension the raised blood pressure is accompanied by a normal cardiac output (Taylor, Donald, and Bishop, 1957). The increased peripheral resistance is uniformly distributed throughout all the regional circulations and resides predominantly in the peripheral arterioles (Freis, 1960). These vessels regulate the resistance in many of the regional vascular beds, and particularly in the kidney, through sympathetic alphaadrenergic receptors (Moran, 1966).

Thus it is reasonable to expect that drugs which possess both vasodilator properties and also the ability to inhibit stimulation of the adrenergic alpha-receptors may offer substantial advantages over other less specific agents in the treatment of hypertensive vascular disease. Phentolamine, an alpha-receptor antagonist with conspicuous vasodilator properties (Taylor et al., 1965a, b; Majid, Sharma, and Taylor, 197I), has been shown to be effective in acutely lowering the blood pressure of hypertensive patients (Taylor et al., 1965a). However, in subjects with intact cardiovascular reflexes the hypotensive effects of the drug are offset by an accompanying increase in cardiac output (Taylor

Received 29 January 1974.

1 Present address: Royal Victoria Infirmary, Newcastle upon Tyne. et al., 1965a; Majid et al., 1971). For this reason it is logical to combine drugs that block both the alphaand beta-adrenoreceptors so that the reflex increase in sympathetic stimulation of the heart that occurs in response to the fall in blood pressure induced by alpha-receptor blockade is prevented by inhibition of the cardiac beta-receptors.

The following investigation was, therefore, undertaken to test this thesis by acute haemodynamic studies in patients with severe hypertensive disease and to determine the clinical effectiveness of the combination of oral alpha- and beta-receptor antagonists in the longer term treatment of these patients.

\section{Patients and methods}

Twelve patients with severe uncomplicated essential hypertension were studied. Five were men, average age 47 years (range 44 to 50 years) and average weight $89 \mathrm{~kg}$ (range 84 to $98 \mathrm{~kg}$ ); 7 were women average age 4I years (range 34 to 49 years) and average weight $60 \mathrm{~kg}$ (range 49 to $83 \mathrm{~kg}$ ). Seven patients presented with severe headaches which had proved intractable to other antihypertensive drugs, singly or in combination. In the remainder a high blood pressure was discovered during routine medical examination for minor illnesses. The lowest diastolic pressure measured in the supine position by doctors in the ward persistently exceeded $120 \mathrm{mmHg}$ (range 120 to 150 ) in all patients during their hospital 

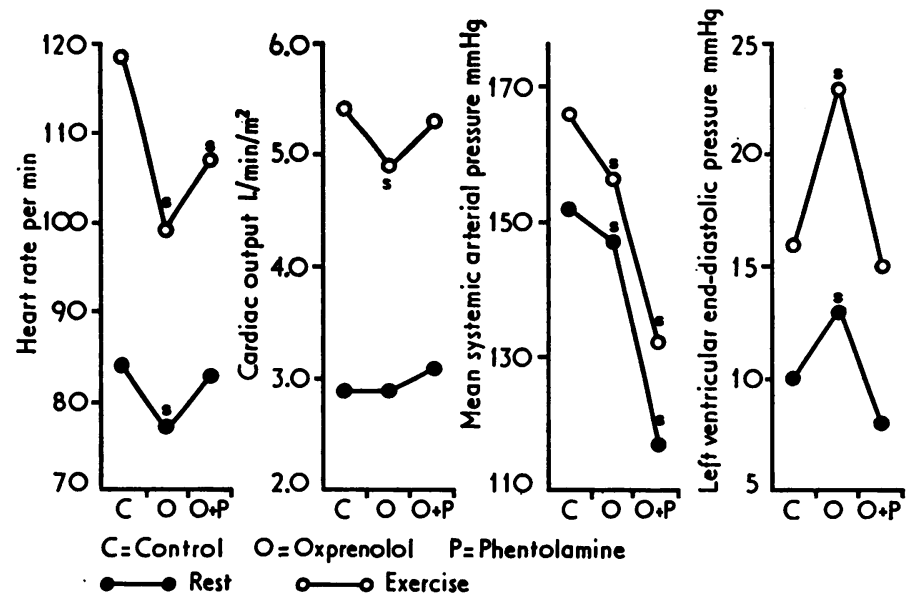

FIG. I Haemodynamic effects of intravenous alpha- and beta-receptor antagonists, singly and in combination, at rest and during supine leg exercise, in hypertensive patients. Symbols represent mean values. ' $S$ ' indicates significant difference from control value at a probability of 5 per cent or less.

admission. None had papilloedema or fundal haemorrhages or exudates and none had proteinuria. No patient had a history of myocardial infarction, congestive heart failure, or cerebrovascular disease. In ro patients there was electrocardiographic evidence of left ventricular hypertrophy $\left(R_{\mathrm{aVL}}>\mathrm{I} 3 \mathrm{~mm} ; \mathbf{R}_{\mathrm{V} 5-6}>27 \mathrm{~mm} ; \mathrm{S}_{\mathrm{V} 1}+\mathbf{R}_{\mathrm{V} 5-6}>\right.$ $35 \mathrm{~mm}$ ). In all, the radiographic silhouette suggested concentric left ventricular hypertrophy but in none was the heart dilated (cardiothoracic ratio $<55 \%$ ). Intravenous pyelography and 24-hour creatine clearance tests were normal in all. Endocrine abnormalities were eliminated by appropriate tests.
The scientific reasons for the study, the proposed programme of investigation, its relation to their individual treatment, and its possible wider therapeutic implications were explained to each patient; the voluntary nature of the co-operation requested was emphasized. All patients freely consented to the study without inducement (Medical Research Council, I964; Ormrod, 1968).

\section{Design of investigation}

Patients were admitted to hospital for baseline measurements of blood pressure and routine investigations to

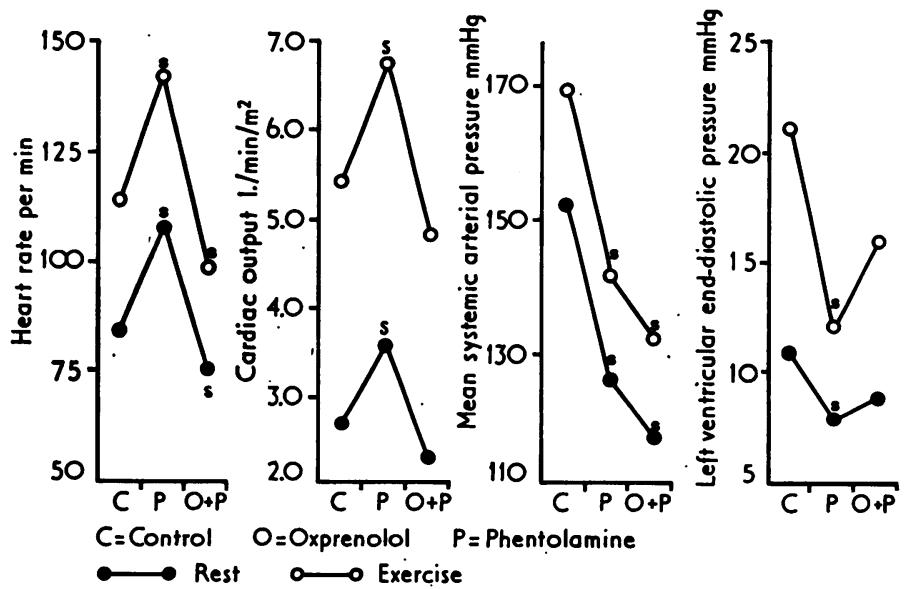

FIG. 2 Haemodynamic effects of intravenous alpha- and beta-receptor antagonists, singly and in combination, at rest and during supine leg exercise, in hypertensive patients. Symbols represent mean values. ' $S$ ' indicates significant difference from control value at a probability of 5 per cent or less. 
exclude an underlying cause for the raised blood pressure. All were kept active throughout the day to prevent the fall in blood pressure associated with bed rest.

A) Haemodynamic studies Patients were familiarized with the laboratory staff and environment and at the same time trained to exercise in the supine position on a bicycle ergometer. A common level of submaximal supine leg exercise was selected which all could achieve without discomfort. The bicycle ergometer work load was chosen to give an oxygen uptake similar to that produced by treadmill walking at 2 m.p.h. on a $10^{\circ}$ incline, the level of exertion used in the followthrough long-term oral studies. Patients were alternately allocated into one of two groups of six. In group A, the effects of the beta-receptor antagonist oxprenolol $(0.2$ $\mathrm{mg} / \mathrm{kg}$ body weight) were studied first before the addition of the alpha-receptor inhibitor phentolamine $(0.5-1.0 \mathrm{mg} / \mathrm{min})$. In group B the order of drug administration was reversed. Oxprenolol was given as a bolus injection and phentolamine as a constant infusion through separate lumens of a catheter in the pulmonary artery.

The definitive studies were carried out in the morning, two hours after a light meal without premedication.

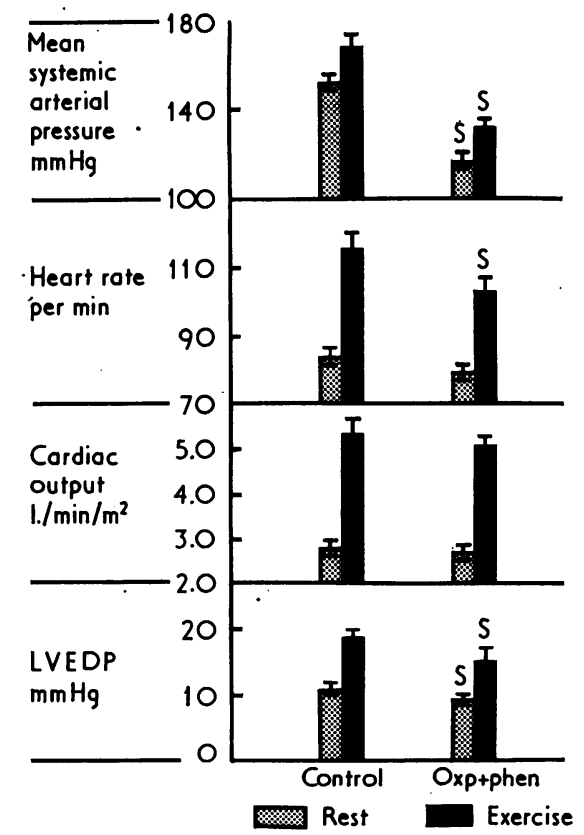

FIG. 3 Haemodynamic effects of intravenous alphaand beta-receptor antagonists at rest and during supine leg exercise in hypertensive patients. Histograms represent mean values at $\pm S$.E.M. ' $S$ ' indicates significant difference from control value at a probability of 5 per cent or less.

Oxp $=$ oxprenolol. Phen $=$ phentolamine.

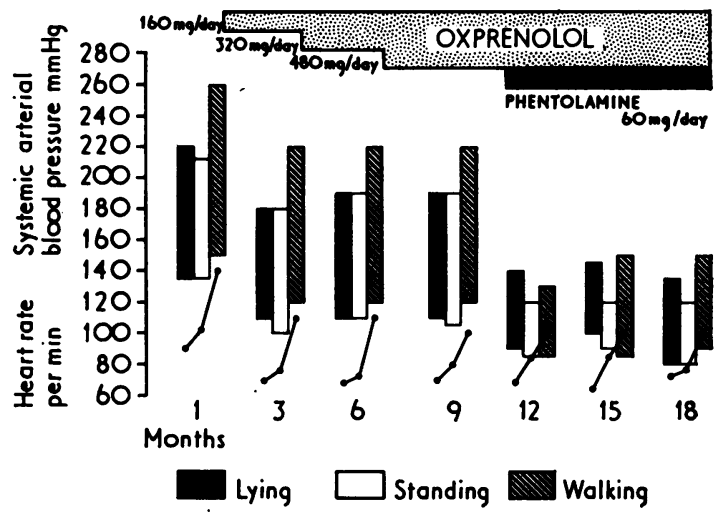

FIG. 4 Effects of oral alpha- and beta-receptor antagonists, singly and in combination, during longterm treatment of a hypertensive patient.

Observations began 30 minutes after introducing a multilumen catheter into the pulmonary artery and nylon catheters $(75 \times 0.1 \mathrm{~cm})$ into the aorta and left ventricle.

In group $A$, the programme of investigation started with 6 minutes of supine leg exercise followed by 20 minutes of rest. Oxprenolol was then injected and I5 minutes later the rest and exercise studies were repeated in reverse order. At the end of the second 6-minute period of exercise, phentolamine infusion was started and the rate adjusted to lower the mean systemic arterial pressure to 20 to $30 \mathrm{mmHg}$. Twenty minutes later the rest and exercise studies were repeated for the third time. In group $B$ the order of drug administration was reversed; the infusion of phentolamine was temporarily discontinued during the second post-exercise recovery period in this group so that patients in both groups received approximately the same total amount of phentolamine $(20-40 \mathrm{mg})$. The times and doses of phentolamine and oxprenolol used were decided after pilot studies in ourselves had confirmed the effectiveness of each drug in producing a conspicuous degree of alphaor beta-receptor blockade over the time scale of the intended investigation. Cardiac output was measured by the direct oxygen Fick method during the last four minutes of each rest period and during the final two minutes of each exercise period. Intravascular pressures and electrocardiogram were displayed and recorded continuously throughout.

B) Clinical studies An oral preparation of phentolamine was supplied at our special request by Ciba Laboratories, Horsham, after initial studies had confirmed the antihypertensive effectiveness of the intravenous preparation in combination with oxprenolol. Thus, only the last six patients were able to be treated on a direct follow-through basis from the intravenous studies, without the intervention of other antihypertensive treatment. 
During their initial hospital admission 6 patients were walked daily on a motor-driven treadmill at $2 \mathrm{~m}$.p.h. on a $10^{\circ}$ incline for 10 minutes, a level of exercise that was well within the usual range of their normal everyday exertion. Sphygmomanometric blood pressure and electrocardiographically determined heart rate were measured in duplicate after lying supine for to minutes, after standing for 3 minutes, and at minute intervals during treadmill walking for Io minutes; values used for analysis were the average of measurements taken at the 8th, 9th, and roth minute of walking. Control values were furnished by six daily studies on each patient before the haemodynamic investigation. Treatment was started the day after the circulatory studies with oxprenolol $40 \mathrm{mg}$ q.d.s. ( $160 \mathrm{mg}$ daily). Patients were discharged from hospital a few days later and followed up at fortnightly intervals. At each follow-up blood pressure and heart rate were measured lying, standing, and at the same speed of treadmill walking as during the control studies. The dose of oxprenolol was increased at 2monthly intervals up to a maximum of $160 \mathrm{mg}$ t.d.s. ( $480 \mathrm{mg}$ daily) where it was held for 3 months to measure any habituation effects. This dose of exprenolol was chosen as the final dose as previous studies in this laboratory had shown that $160 \mathrm{mg}$ oxprenolol induces a substantial suppression of the circulatory response to exercise for up to 8 hours (Taylor et al., 1974). Phentolamine $20 \mathrm{mg}$ t.d.s. ( $60 \mathrm{mg}$ daily) was then added to this regimen and out-patient observations continued. This dose of phentolamine was used as preliminary observations conducted throughout the day showed that $20 \mathrm{mg}$ produced its maximal antihypertensive effect within one hour with an effective duration of 3 to 6 hours (Fig. 5). Similar hour-by-hour studies were carried out in each patient at monthly intervals after the addition of phentolamine to determine the magnitude and duration of its antihypertensive activity in these circumstances. At each out-patient clinic, bodyweight, serum, sodium, potassium, chloride, and urea, and electrocardiogram were also examined; standard chest radiographs were taken at monthly intervals.

\section{Laboratory techniques, measurements, and statistics}

The haemodynamic methods of investigation used in this study have been reported in detail previously (Majid et al., 1971; Sharma et al., 1972). In this laboratory, using such methods under similar conditions of study, duplicate measurements of oxygen uptake, cardiac output, intravascular pressures, and left ventricular enddiastolic pressure agreed within $5,7,3$, and 8 per cent, respectively. To avoid observer bias during the oral treatment period, brachial arterial blood pressure was measured with a sphygmomanometer incorporating a randomly offset zero (Hawksley-Gelman), (Garrow, 1963; Evans and Prior, 1970; Wright and Dore, 1970). Pressure measurements were made in duplicate and read to the nearest $2 \mathrm{mmHg}$. For clarity of tabulation (Table 2) measurements were averaged throughout each period in each subject. The probability of statistical significance of changes compared to the control observations was calculated by Student's ' $t$ ' test for paired data.

\section{Results \\ Haemodynamic studies \\ No symptomatic side effects followed the intravenous administration of either drug alone or in combina- tion in any patient. The electrocardiogram was continuously monitored and did not reveal any dysrhythmia or any other change during or after the injection of either phentolamine or oxprenolol.}

Group A (Fig. I, Table I) Oxprenolol alone produced a reduction in heart rate and mean systemic arterial pressure and rise in left ventricular

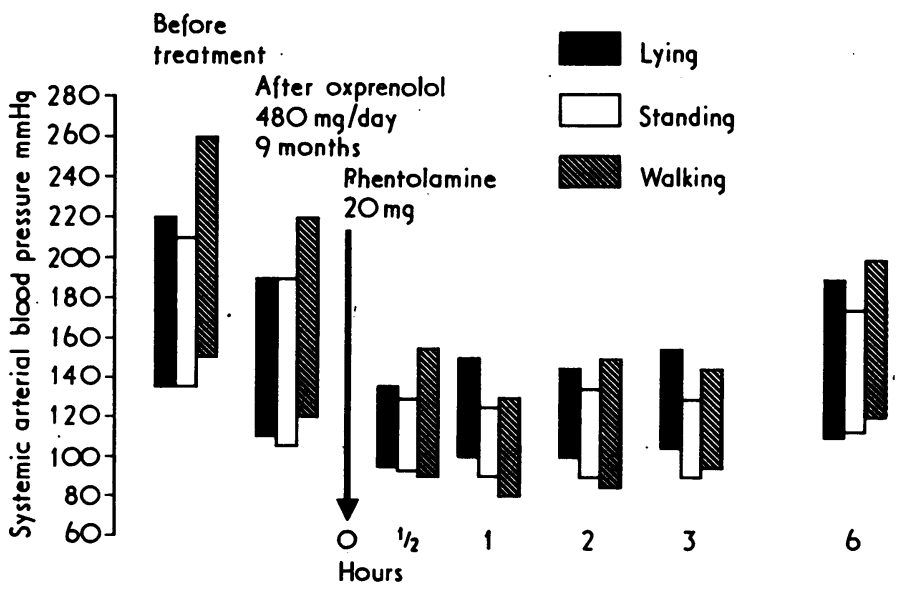

FIG. 5 Magnitude and duration of action of a single oral dose of $20 \mathrm{mg}$ phentolamine on the blood pressure of a hypertensive patient pretreated with $480 \mathrm{mg}$ oral oxprenolol daily. 
TABLE I Haemodynamic effects of adrenergic alpha- and beta-receptor antagonists singly and combined in hypertensive patients

\begin{tabular}{|c|c|c|c|c|c|c|}
\hline \multirow[t]{2}{*}{ Variable } & \multirow[t]{2}{*}{ State } & \multicolumn{3}{|c|}{ Group $A(6)$} & \multicolumn{2}{|c|}{ Group $B(6)$} \\
\hline & & Control & Oxprenolol & $\begin{array}{l}\text { Oxprenolol+ } \\
\text { phentolamine }\end{array}$ & Control & Phentolamine \\
\hline $\begin{array}{l}\text { Oxygen uptake } \\
\left(\mathrm{ml} / \mathrm{min}_{\mathrm{m}} \mathrm{per} \mathrm{m}^{2}\right) \\
\text { Cardiac output } \\
\text { l./min per } \mathrm{m}^{2} \\
\text { Heart rate/min } \\
\\
\text { Mean systemic arterial } \\
\text { pressure (mmHg) } \\
\text { Left ventricular end- } \\
\text { diastolic pressure }(\mathrm{mmHg})\end{array}$ & $\begin{array}{l}\left\{\begin{array}{l}\mathbf{R} \\
\mathbf{E x} \\
\mathbf{R}\end{array}\right. \\
\mathbf{E x} \\
\left\{\begin{array}{l}\mathbf{R} \\
\mathbf{E x}\end{array}\right. \\
\left\{\begin{array}{l}\mathbf{R} \\
\mathbf{E x} \\
\mathbf{R} \\
\mathbf{E x}\end{array}\right.\end{array}$ & $\begin{array}{l}140 \pm 12 \\
436 \pm 26 \\
2 \cdot 9 \pm 0 \cdot 2 \\
5 \cdot 4 \pm 0 \cdot 3 \\
84 \pm 5 \\
119 \pm 7 \\
152 \pm 7 \\
166 \pm 8 \\
10 \pm 1 \\
16 \pm 2\end{array}$ & $\begin{array}{l}152 \pm 9 \\
432 \pm 17 \\
2 \cdot 8 \pm 0 \cdot 2 \\
4 \cdot 8 \pm 0 \cdot 2^{\star} \\
77 \pm 4^{\star} \\
99 \pm 5 \ddagger \\
147 \pm 7^{\star} \\
156 \pm 7 \ddagger \\
13 \pm 2^{\star} \\
24 \pm 3 \ddagger\end{array}$ & $\begin{array}{l}162 \pm 11 \\
420 \pm 35 \\
3 \cdot 1 \pm 0 \cdot 1 \\
5 \cdot 3 \pm 0 \cdot 2 \\
83 \pm 5 \\
107 \pm 6 \dagger \\
117 \pm 65 \\
132 \pm 75 \\
8 \pm 1 \\
15 \pm 3\end{array}$ & $\begin{array}{l}142 \pm 11 \\
461 \pm 44 \\
2 \cdot 7 \pm 0 \cdot 2 \\
5 \cdot 4 \pm 0 \cdot 3 \\
85 \pm 4 \\
114 \pm 8 \\
152 \pm 7 \\
169 \pm 8 \\
11 \pm 1 \\
21 \pm 3\end{array}$ & $\begin{array}{l}154 \pm 7 \\
576 \pm 35 \\
3 \cdot 6 \pm 0 \cdot 3^{\star} \\
6 \cdot 7 \pm 0 \cdot 3 \ddagger \\
108 \pm 10^{\star} \\
142 \pm 13 \ddagger \\
126 \pm 8 \dagger \\
141 \pm 7^{\star} \\
8 \pm 1^{\star} \\
12 \pm 2 \ddagger\end{array}$ \\
\hline
\end{tabular}

Number of patients in each group in parentheses. Data expressed as mean \pm standard error of mean. $R$, rest; Ex, exercise. Probabilities relate to the significance of difference between paired data as compared to the control: $P<0.05^{\star} ; \mathrm{P}<0.02 \dagger$; $\mathbf{P}<0.01 \ddagger$; $\mathbf{P}<0.001$.

end-diastolic pressure both at rest and during exercise; cardiac output was unchanged at rest but reduced during exercise. The addition of phentolamine produced a more substantial decrease in mean systemic arterial pressure: this was accompanied by a reduction in the left ventricular end-diastolic pressure to control levels and an increase in the heart rate both at rest and during exercise. Cardiac output was unchanged from control values.

Group B (Fig. 2, Table I) Phentolamine alone induced a conspicuous fall in mean systemic arterial pressure both at rest and during exercise. This was accompanied by an increased heart rate and cardiac output and a reduction in left ventricular end-diastolic pressure. The addition of oxprenolol reduced the heart rate and cardiac output to near control values, reduced the mean systolic arterial pressure still further, and increased the left ventricular end-diastolic pressure towards control volumes.

Combined results (Fig. 3, Table I) The net result of oxprenolol and phentolamine together in all 12 patients was a reduction in systemic arterial pressure to normal levels both at rest and during exercise. This was achieved without any change in the normal resting cardiac output or in the output response to exercise. There was a significant reduction in the left ventricular end-diastolic pressure both at rest and during exertion.

\section{Clinical studies (Fig. 4, Table 2)}

There was a gradual reduction in systemic pressure both lying and standing at rest and also during exercise as the dose of oxprenolol was increased. But in only 2 of the 6 patients was there a further fall in blood pressure when the dose was increased from 320 to $480 \mathrm{mg}$ daily. No further fall in blood pressure was observed in any patient when $480 \mathrm{mg}$ oxprenolol alone daily was continued for three months. No postural effects on the blood pressure were observed. There was a conspicuous reduction in the heart rate lying, standing, at rest, and during walking in all patients. On this regimen the only complaint was that of tiredness of the legs when climbing stairs or hurrying.

The addition of phentolamine produced a further substantial reduction in systemic blood pressure to normal levels both at rest and during exercise without symptomatic postural effects. The magnitude and duration of the antihypertensive activity of oral phentolamine in these circumstances is illustrated in Fig. 5. The reduction in systolic and diastolic pressures after the addition of phentolamine to oxprenolol was statistically significant lying (systolic: $\mathbf{P}<0.001$; diastolic: $P<0.01$ ), standing (systolic: $\mathbf{P}<0.01$; diastolic: $\mathbf{P}<0.00 \mathrm{I}$ ), and walking (systolic: $\mathbf{P}<0.01$; diastolic: $\mathbf{P}<0.05$ ) compared to the values with oxprenolol alone. The effect on the blood pressure of the combination of oxprenolol and phentolamine persisted unchanged for more than 6 months, the minimum length of study in all subjects.

No side effects of the combined oral treatment were observed except in one patient who complained of slight nausea on first taking phentolamine; this symptom disappeared when the tablets were taken with food. Throughout the year of follow-up in each of these patients, no changes were 
TABLE I (Cont'd)

\begin{tabular}{ccc}
\hline & \multicolumn{2}{l}{ Groups $A$ and $B(I 2)$} \\
\hline $\begin{array}{l}\text { Phentolamine } \\
\text { +oxprenolol }\end{array}$ & Control & $\begin{array}{c}\text { Phentolamine } \\
+ \text { oxprenolol }\end{array}$ \\
\hline $141 \pm 8$ & & $151 \pm 7$ \\
$442 \pm 37$ & $141 \pm 8$ & $431 \pm 25$ \\
$2 \cdot 4 \pm 0 \cdot 1$ & $449 \pm 25$ & $2 \cdot 7 \pm 0 \cdot 2$ \\
$4 \cdot 9 \pm 0 \cdot 4$ & $2 \cdot 8 \pm 0 \cdot 2$ & $5 \cdot 1 \pm 0 \cdot 2$ \\
$76 \pm 4^{\star}$ & $5 \cdot 4 \pm 0 \cdot 3$ & $79 \pm 3$ \\
$99 \pm 5 \ddagger$ & $84 \pm 3$ & $103 \pm 4 \S$ \\
$117 \pm 6 \ddagger$ & $116 \pm 5$ & $117 \pm 4 \oint$ \\
$132 \pm 5 \ddagger$ & $152 \pm 4$ & $132 \pm 4 \oint$ \\
$9 \pm 1$ & $168 \pm 6$ & $8 \pm 1 \ddagger$ \\
$16 \pm 3$ & $11 \pm 1$ & $15 \pm 2 \ddagger$ \\
& $19 \pm 1$ & \\
\hline
\end{tabular}

observed in body weight, blood electrolytes, standard liver function tests, electrocardiogram, or chest radiograph. Four of the six patients complained of severe headaches before treatment; all are now symptom free.

\section{Discussion}

The rationale for the use of vasodilator drugs in combination with beta-receptor antagonists in the treatment of essential hypertension was outlined in the introduction to this report. The results of the haemodynamic studies support the thesis that partial blockade of the cardiac beta-receptors augments the blood pressure lowering effects of the vasodilator and alpha-receptor antagonist phentolamine by reducing the sympathetic stimulation of the heart that occurs in response to the fall in blood pressure. The blockade of the cardiac beta-receptors can also be expected to counteract the cardiac stimulation that results from the release of endogenous catecholamines by phentolamine (Gould, Zahir, and Ettinger, 1969). Oxprenolol and phentolamine in combination produced a more conspicuous reduction in blood pressure than either drug alone. Furthermore, the increase in left ventricular enddiastolic pressure due to beta-blockade alone was nullified by the addition of phentolamine, and conversely the disadvantageous tachycardia and increase in cardiac output with phentolamine alone was completely counteracted by the addition of oxprenolol. In these haemodynamic terms, the

TABLE 2 Results of oral treatment of hypertensive patients with alpha-and beta-receptor antagonists

\begin{tabular}{|c|c|c|c|c|c|c|c|c|c|c|c|}
\hline \multirow{2}{*}{$\begin{array}{l}\text { Case } \\
\text { No. }\end{array}$} & \multirow{2}{*}{$\begin{array}{l}\text { Sex, } \\
\text { age }(y r), \\
\text { wt (kg) }\end{array}$} & \multirow[t]{2}{*}{ Variable } & \multicolumn{3}{|l|}{ Control } & \multicolumn{3}{|c|}{ Oxprenolol } & \multicolumn{3}{|c|}{ Oxprenolol and phentolamine } \\
\hline & & & Lying & Standing & Walking & Lying & Standing & Walking & Lying & Standing & Walking \\
\hline & (F & Systolic & 221 & 212 & 258 & 192 & 188 & 220 & 138 & 130 & 145 \\
\hline \multirow[t]{3}{*}{$\mathbf{I}$} & 49 & Diastolic & 133 & 135 & 148 & 112 & 108 & 117 & 88 & 82 & 91 \\
\hline & 54 & HR & 88 & 98 & 137 & 72 & 78 & II 2 & 76 & 81 & II 4 \\
\hline & F & Systolic & 218 & 213 & 231 & 166 & 162 & 183 & I46 & 138 & 148 \\
\hline \multirow[t]{3}{*}{2} & 46 & Diastolic & I2I & 124 & 127 & 118 & $12 \mathbf{I}$ & 129 & 94 & 90 & 95 \\
\hline & 66 & HR & $8 I$ & 96 & 122 & 69 & 72 & 98 & 72 & 85 & 106 \\
\hline & C F & Systolic & 188 & 189 & 221 & 172 & 173 & 188 & 158 & 145 & 160 \\
\hline \multirow[t]{3}{*}{3} & 44 & Diastolic & 122 & I2I & 129 & 109 & 112 & II5 & 98 & 95 & 98 \\
\hline & 52 & HR & 80 & 99 & 135 & 68 & 76 & 113 & 78 & 90 & 116 \\
\hline & (M & Systolic & 219 & 215 & 245 & 187 & 192 & 223 & 145 & 140 & 156 \\
\hline \multirow[t]{3}{*}{4} & $\{54$ & Diastolic & 120 & 120 & 141 & 104 & 109 & 116 & 95 & 90 & 94 \\
\hline & 76 & HR & 70 & 84 & II2 & 60 & 67 & 106 & 68 & 82 & 108 \\
\hline & M & Systolic & 202 & 201 & 274 & 168 & 169 & 179 & 136 & 125 & 132 \\
\hline \multirow[t]{3}{*}{5} & $\{53$ & Diastolic & 122 & 125 & 148 & II 8 & 121 & 124 & 91 & 89 & 96 \\
\hline & 82 & HR & 78 & 83 & 127 & 73 & 75 & 108 & 75 & 81 & II \\
\hline & $(\mathbf{M}$ & Systolic & 219 & 220 & $23 \mathrm{I}$ & 170 & 163 & 192 & 148 & 145 & 159 \\
\hline \multirow[t]{2}{*}{6} & $\{52$ & Diastolic & 128 & 130 & 143 & 109 & 109 & 116 & 89 & 86 & 90 \\
\hline & 80 & HR & 73 & 80 & 123 & 67 & 70 & 105 & 70 & 80 & IIo \\
\hline Mean & & Systolic & $210 \pm 5$ & $208 \pm 5$ & $240 \pm 8$ & $175 \pm 5 \ddagger$ & $175 \pm 6 \ddagger$ & 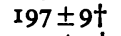 & $I 43 \pm 4 \ddagger$ & $137 \pm 5 \S$ & $150 \pm 65$ \\
\hline$\stackrel{ \pm}{\text { SEM }}$ & & $\begin{array}{l}\text { Diastolic } \\
\text { HR }\end{array}$ & $\begin{array}{r}124 \pm 3 \\
78 \pm 3\end{array}$ & $\begin{array}{r}126 \pm 3 \\
90 \pm 4\end{array}$ & $\begin{array}{l}139 \pm 4 \\
126 \pm 6\end{array}$ & $\begin{array}{r}112 \pm 3 \ddagger \\
68 \pm 4 \dagger\end{array}$ & $\begin{array}{r}113 \pm 3 \ddagger \\
73 \pm 4 \ddagger\end{array}$ & $\begin{array}{l}119 \pm 5 \ddagger \\
107 \pm 5 t\end{array}$ & $\begin{array}{l}90 \pm 3 \ddagger \\
73 \pm 4^{\star}\end{array}$ & $\begin{array}{l}89 \pm 3 \ddagger \\
83+47\end{array}$ & $\begin{array}{r}94 \pm 35 \\
\text { III } \pm 35\end{array}$ \\
\hline
\end{tabular}

Data given relate to averages of measurements in each period.

Probabilities relate to the significance of difference of the paired data from the control value.

$\mathbf{P}<0.95^{\star} ; \mathbf{P}<0.02 \dagger ; \mathrm{P}<0.01 \neq ; \mathrm{P}<0.001$. 
circulation of these severely hypertensive patients could not be distinguished from that of normal subjects after this combination of drugs. Such beneficial circulatory results have rarely been achieved by other antihypertensive drugs in common use singly or in combination.

The clinical follow-up studies with oral treatment of these patients with this combination of drugs were equally promising. Though oxprenolol alone produced a moderate reduction in the arterial pressure in the majority of the patients, in none was the blood pressure of these severely hypertensive patients reduced to clinically satisfactory levels. The addition of a relatively small dose of oral phentolamine to this regimen produced a further conspicuous reduction in blood pressure, in every patient to normal levels without postural hypotension and with a normal response (small increase) to exercise. This antihypertensive activity of oral phentolamine was observed for 3 to 6 hours after each oral dose and its effectiveness was maintained in all patients for longer than six months without habituation. The combination of oxprenolol (480 $\mathrm{mg}$ daily) and phentolamine ( $60 \mathrm{mg}$ daily) during this time was unaccompanied by any symptomatic side-effects or any untoward change in body weight, heart size, electrocardiogram, renal, or liver function.

However, the study can be criticized from a number of aspects. The rigid criteria employed for their selection almost certainly resulted in a cohort of patients infrequently seen in routine clinical practice. Though this must necessarily limit the wider clinical application of these results, clinical homogeneity of the patient group is essential if the results of such studies are to be therapeutically valid. It must also be pointed out that no attempt was made to equate the relative degree of either alpha- or betareceptor blockade achieved either in the haemodynamic or in the clinical studies in these patients. The doses of both drugs used in both situations were empirically chosen and no attempt was made to determine the dose-response relation for either drug singly or in combination. In fact, the complete response of all patients in this group of severely hypertensive patients suggests that smaller doses of these drugs, particularly that of the beta-receptor antagonist, may have achieved equally beneficial results; the effects of small doses should certainly be explored in any future trial of alpha- and betablockers in hypertension. Finally, it must be emphasized that though every effort was made to remove measurement bias, as by the use of a randomzero sphygmomanometer, the clinical studies were not double-blind in design. Though these provisos relegate the significance of these results to those of a promising preliminary report, we consider that the objective nature of the measurements furnish sufficient evidence to encourage further investigation of this treatment in severe hypertension.

Vasodilator drugs with alpha-receptor blocking activity in combination with beta-receptor antagonists have two distinct advantages over the use of beta-receptor inhibitors alone in the treatment of hypertension. The reduction in blood pressure produced by vasodilator drugs results in a lowering of impedance to ejection of blood from the ventricle, thus reducing left ventricular pressure work. The beta-receptor antagonists reduce blood pressure largely by reducing cardiac output, peripheral resistance remaining unchanged or even increasing (Majid et al., 1970). The effects on the heart of these two methods of achieving blood pressure reduction were clearly contrasted in the present study. Phentolamine resulted in a reduction in blood pressure and a decrease in left ventricular enddiastolic pressure. Beta-receptor blockade alone resulted in a lesser reduction in blood pressure at the expense of an increase in left ventricular enddiastolic pressure. In combination the antihypertensive effects of the two drugs were summated and associated with a reduction in left ventricular enddiastolic pressure. The other major advantage of the drugs that block vasoconstrictive alpha-receptors in the treatment of hypertensive disease depends on their ability to inhibit the renal vascular effects of sympathetic stimuli. The alpha-receptors play a key role in the regulation of the circulation through the kidney (Handley and Moyer, 1954). An increase in sympathetic activity whether due to emotion, excitement, exercise, trauma, or the incidental fall in blood pressure that occurs after beta-receptor antagonists alone, results in vasoconstriction of the renal vessels due to alpha-receptor activity. Blockade of these receptors by preventing or reducing such frequent shutdown of the renal vessels may retard or even prevent the progression of renal vascular disease, which is still one of the major causes of death in hypertension (Smirk and Hodge, 1963).

A number of studies involving selective blockade of the sympathetic alpha- and beta-receptors alone or in combination have been reported. Alone, the alpha-receptor antagonists never achieved popularity in the treatment of hypertension. Though phentolamine was specifically introduced for this purpose (Moyer and Caplovitz, 1953), doses up to $900 \mathrm{mg}$ daily were necessary to achieve a satisfactory reduction in blood pressure; these doses frequently induced gastrointestinal disturbances. Phenoxybenzamine, another alpha-receptor antagonist likewise never found wide favour in the treatment of hypertension, probably because of its 
pronounced cumulative effects (Nickerson, 1962). Hydralazine, a vasodilator drug with weak alphareceptor blocking activity achieved a temporary popularity (Freis, 1962), but the high doses necessary to achieve satisfactory control of the blood pressure with this drug alone often gave rise to unpleasant side effects and its use was quickly curtailed. Beta-receptor antagonists alone have also been advanced in the treatment of hypertension (Prichard and Gillam, 1969; Zacharias and Cowen, 1970). However, the large doses (e.g. 1000 mg propranolol daily or more) often necessary to achieve a satisfactory reduction in the blood pressure of severely hypertensive patients, the frequency of inadequate blood pressure control despite such large doses, and the possible long-term deleterious effects of such high doses on left ventricular function (Majid et al., 1970), have resulted in some waning of interest in the use of these drugs alone in the treatment of severe hypertensive disease. This has led to the consideration that both types of drug together may be more effective than either alone, and recently several claims have been made for the antihypertensive effectiveness of combined selective sympathetic blockade. Consistent control of the blood pressure in hypertensive patients has been achieved with vasodilator drugs in combination with beta-receptor antagonists in acute intravenous studies (Sannerstedt et al., 197I), in short-term oral studies (Gilmore, Weil, and Chidsey, 1970; Katila and Frick, 1970; Hansson et al., 197I; Sannerstedt et al., 1972; Zacest, Gilmore, and Koch-Wesser, 1972), and during single-blind trials (Aenishänslin et al., 1972). The absence of potentiation or the development of side effects with such combined treatment reported in previous open (Hansson et al., 1971), single-blind (Aenishänslin et al., 1972) or double-blind (Beilin and JuelJenson, 1972) trials is probably explicable on the basis that in the majority of instances the vasodilator drugs used had only weak alpha-blocking activity, e.g. hydralazine, or cumulative side effects, e.g. phenoxybenzamine, or that the trial incorporated a fixed dose regimen. Comparison of these reported results with those of the present study indicates the clinical importance of the choice of drugs used and the necessity of titration of their dosage against the blood pressure in each individual patient. In hypertension, in which the sympathetic component of the blood pressure is so variable, fixed-dose drug schedules probably have no place in the treatment of the individual patient. Though we found that the combination of phentolamine $20 \mathrm{mg}$ and oxprenolol $\mathrm{I} 60 \mathrm{mg}$ each thrice daily was effective in all the patients we studied, the group was small and selected only to include patients with par- ticular severe disease; smaller doses of both drugs may be equally efficacious in patients with less severe hypertension.

We consider that these studies provide sufficient physiological and clinical evidence to warrant further clinical trials in the use of combined alphaand beta-receptor blockade in the treatment of severe hypertension.

P.A.M. is a Senior Wellcome Foundation Research Fellow; M.K.M. and B.S. are Senior Ciba Research Fellows.

This work was assisted by a grant from Wellcome Foundation and the West Riding Medical Research Trust.

\section{References}

Aenishänslin, W., Pestalozzi-Kerpel, J., Dubach, U. C., Imhof, P. R., and Turri, M. (1972). Antihypertensive therapy with adrenergic beta-receptor blockers and vasodilators. European fournal of Clinical Pharmacology, 4, 177.

Beilin, L. J., and Juel-Jenson, B. E. (1972). Alpha and betaadrenergic blockade in hypertension. Lancet, $1,979$.

Evans, J. G., and Prior, I. A. M. (1970). Experience with the random-zero sphygmomanometer. British fournal of Preventive and Social Medicine, 24, ro.

Freis, E. D. (1960). Hemodynamics of hypertension. Physiological Reviews, 40, 27.

Freis, E. D. (1962). Hydralazine: pharmacology and clinical application. In Recent Advances in Hypertension, the 2nd Hahnemann Symposium in Hypertensive Disease, p. 291. Ed. by A. N. Brest and J. H. Moyer. Henry Kimpton, London.

Garrow, J. S. (1963). Zero-muddler for unprejudiced sphygmomanometry. Lancet, 2, 1205.

Gilmore, E., Weil, J., and Chidsey, C. (1970). Treatment of essential hypertension with a new vasodilator in combination with beta-adrenergic blockade. New England fournal of Medicine, 282, $52 \mathrm{r}$.

Gould, L., Zahir, M., and Ettinger, S. (1969). Phentolamine and cardiovascular performance. British Heart fournal, 3I, I54.

Handley, C. A., and Moyer, J. H. (1954). Unilateral renal adrenergic blockade and the renal response to vasopressor agents and to hemorrhage. fournal of Pharmacology and Experimental Therapeutics, 112, 1.

Hansson, L., Olander, R., Aberg, H., Malmcrona, R., and Westerlund, A. (I97I). Treatment of hypertension with propranolol and hydralazine. Acta Medica Scandinavica, 190, 531 .

Katila, M., and Frick, M. H. (1970). Combined dihydralazine and propranolol in the treatment of hypertension. Internationale Zeitschrift fur Klinische Pharmakologie, Therapie und Toxikologie, 4, III.

Majid, P. A., Sharma, B., Saxton, C., Stoker, J. B., and Taylor, S. H. (1970). Haemodynamic effects of oxprenolol in hypertensive patients. Postgraduate Medical fournal, 46, November Suppl., 67.

Majid, P. A., Sharma, B., and Taylor, S. H. (197I). Phentolamine for vasodilator treatment of severe heart-failure. Lancet, 2, 719.

Medical Research Council (1964). Annual Report, 1962-63. Statement on responsibility in investigations on human subjects. British Medical fournal, 2, 178. 
Moran, N. C. (1966). Adrenergic receptors, drugs, and the cardiovascular system. Modern Concepts of Cardiovascular Disease, 35, 93.

Moyer, J. H., and Caplovitz, C. (1953). Clinical results of oral and parenteral administration of $2-\left(N^{\prime} p-t o l y l-N '-M-\right.$ hydroxyphenylaminomethyl) imidazoline hydrochloride (Regitine) in the treatment of hypertension and an evaluation of the cerebral hemodynamic effects. American Heart fournal, 45, 602.

Nickerson, M. (1962). Mechanism of the prolonged adrenergic blockade produced by haloalkylamines. Archives Internationales de Pharmacodynamie et de Thérapie, 140, 237.

Ormrod, R. (1968). Medical ethics. British Medical fournal, 2 7.

Prichard, B. N. C., and Gillam, P. M. S. (1969). Treatment of hypertension with propranolol. British Medical fournal, I, 7 .

Sannerstedt, R., Stenberg, J., Johnsson, G., and Werko, L. (197I). Hemodynamic interference of alprenolol with dihydralazine in normal and hypertensive man. American Fournal of Cardiology, 28, 316.

Sannerstedt, R., Stenberg, J., Vedin, A., Wilhelmsson, C., and Werko, L. (1972). Chronic beta-adrenergic blockade in arterial hypertension. Hemodynamic influences of dihydralazine and dynamic exercise and clinical effects of combined treatment. American fournal of Cardiology, 29, 718.

Sharma, B., Majid, P. A., Meeran, M. K., Whitaker, W., and Taylor, S. H. (1972). Clinical, electrocardiographic, and haemodynamic effects of digitalis (ouabain) in angina pectoris. British Heart fournal, 34, $63 \mathrm{I}$.
Smirk, H., and Hodge, J. V. (1963). Causes of death in treated hypertensive patients: based on 82 deaths during 1959-6r among an average hypertensive population at risk of 518 persons. British Medical fournal, 2, $122 \mathrm{I}$.

Taylor, S. H., Davidson, C., Thadani, U., and Myint, S. (1974). Comparison of dose-response aspects of betareceptor antagonists in man. In preparation.

Taylor, S. H., Donald, K. W., and Bishop, J. M. (1957) Circulatory studies in hypertensive patients at rest and during exercise, with a note on the Starling relationship in the left ventricle in essential hypertension. Clinical Science, 16, 35I.

Taylor, S. H., Sutherland, G. R., MacKenzie, G. J., Staunton, H. P., and Donald, K. W. (1965a). The cirulatory effects of intravenous phentolamine in man. Circulation, 31, 74I.

Taylor, S. H., Sutherland, G. R., MacKenzie, G. J., Staunton, H. P., and Donald, K. W. (I965b). The circulatory effects of phentolamine in man with particular respect to changes in forearm blood flow. Clinical Science, 28, 265.

Wright, B. M., and Dore, C. F. (1970). A random-zero sphygmomanometer. Lancet, I, 337.

Zacest, R., Gilmore, E., and Koch-Wesser, J. (1972). Treatment of essential hypertension with combined vasodilatation and beta-adrenergic blockade. New England fournal of Medicine, 286, 617.

Zacharias, F. J., and Cowen, K. J. (1970). Controlled trial of propranolol in hypertension. British Medical fournal, $\mathbf{I}$, 471.

Requests for reprints to Dr. S. H. Taylor, Department of Medicine, The Martin Wing, The General Infirmary, Leeds LSI 3 EX. 